\title{
Biological efficacy of agrochemical mikrometsen on sugar beet
}

\author{
Natalia Chernisheva ${ }^{1, *}$, Alla Barchukova ${ }^{1}$, Yanis Tosunov ${ }^{1}$, and Kirill Siniashin ${ }^{2}$ \\ ${ }^{1}$ Kuban State Agrarian University, Kalinina st., 13, Krasnodar, 350044, Russia \\ ${ }^{2}$ Arbuzov Institute of Organic and Physical Chemistry, Arbuzov st., 8, Kazan, 420088, Republic of \\ Tatarstan, Russia
}

\begin{abstract}
The test chemical Mikrometsen - bis (hydroxymethyl) phosphinic acid (mixture of salts) having high growth regulating and antistress property, in case of twice repeated spraying, reinforced growth of beet tops (number of leaves - 20,7-28,0, control - 17,9 pcs/plant; leaves area - 34,72-38,59 $\mathrm{dm}^{2} /$ plant; biomass of leaves - 188,39-248,32, control $161,74 \mathrm{~g} /$ plant) and formation of root crops (length - 29,4-32,3, control $27,8 \mathrm{~cm}$, diameter $-7,4-8,0$, control $-6.9 \mathrm{~cm}$, mass $-438.93-461.24$, control $-417.26 \mathrm{~g})$. It was also established that with an increase in the consumption rate of the chemical, the absolute values of growth and mass indicators of tops and root crops enhanced. The most powerful leaf rosette and large root crops were formed in the option of treatment of sugar beet plants with the chemical Micrometsen twice (1-st in phase of 4-6 leaves, 2nd in 20 days after the first) where the consumption rate was $10 \mathrm{mg} / \mathrm{ha}$ (consumption of working solution $-200 \mathrm{l} / \mathrm{ha}$ ). In this option, the maximum increase in the yield of root crops was obtained $-12.1 \%$, yield under control - 365.9 centner/ha, sugar yield per hectar -70.13 centner (control -58.18 centner).
\end{abstract}

\section{Introduction}

The main source of sugar in Russia is sugar beet, which is cultivated on the area of 1108.1 thousand ha in the Central (56.5\%), Volga (19.1) and Southern (18.5\%) federal districts. This is a highly profitable crop, since it plays an extremely important role for the food security of the Russian Federation, being both a food product for the population and a strategic raw material for the production of organic acids, yeast, alcohol as well as sugar beet pulp obtained during the processing is a valuable feed [1].

The urgent task of sugar beet production is to enhance the productivity of sugar beets and its technological properties.

\footnotetext{
${ }^{*}$ Corresponding author (Автор-корреспондент): $\underline{\text { nv.chernisheva@yandex.ru }}$
} 


\section{Materials and methods}

The aim of the research is to study the effect of the chemical Mikrometsen on the physiological and biochemical properties of sugar beets.

The studies were conducted under conditions of field experiment on low-humus superthick leached soil on the farm "Kuban" of Kuban State Agrarian University (department 1). The accounting area of the plots is $25 \mathrm{~m}^{2}$, the repetition is four times.

The test chemical - Mikrometsen - bis (hidroxymethyl) phosphinic acid is designed to enhance seed germination, yield and nutritional value of the products [1].

The object of the research is a single-seed diploid hybrid of sugar beet Vector, the average yield in the North Caucasus region is 401.3 centner/ha, sugar content $16.5 \%$. The affection by the black leg and powdery mildew, cercosporosis is weak.

In the experimental options, the plants were sprayed twice (the first time - in the phase of 4-6 leaves, again - after 20 days) with Mikrometsen (chemical consumption - 2.5, 5.0 and $10.0 \mathrm{ml} / \mathrm{ha}$; working solution $-200 \mathrm{l} / \mathrm{ha}$ ). Control plants were not treated.

Selection of plant samples (10 typical plants per option) to determine the number of leaves and their surface area (by die-cutting method), tops biomass was carried out in the interlocking of spacing stage. Before harvesting, 10 root crops were selected to determine the parameters of the root crop (length, diameter and mass) and the sugar content (using the refractometric method).

Productivity was calculated by the total pile of harvested from the accounting area root crops. Sugar yield was calculated taking into account the yield and sugar content in root crops.

The data of the performed researches were processed by analysis of variance.

\section{Results and discussions}

The yield of sugar beet largely depends on the size of the leaf rosette, its photosynthetic activity, the ability to accumulate and lay assimilates in root crops, and also withstand various kinds of stress $[3,4,5]$. The growth of the leaf apparatus and root crops during the growing season occurs unevenly. In the first month and a half, leaf growth is ahead of root growth, in the middle of the growing season these values are equalized, leaf growth slows down over the last month and a half, their dying increases, and the total mass of the leaves is $40-60 \%$ of the total mass of the plant.

It is possible to activate the process of leaf formation of sugar beets and the formation of root crops using growth regulators, biologically active substances, new forms of mineral fertilizers in the technology of its cultivation (Table 1) $[6,7,8,9,10,11]$.

Table 1. Effect of Mikrometsen on the growth of sugar beet tops

\begin{tabular}{|l|c|c|c|c|}
\hline \multirow{2}{*}{ Option } & \multirow{2}{*}{$\begin{array}{c}\text { Amount of } \\
\text { leaves } \\
\end{array}$} & \multirow{2}{*}{$\begin{array}{c}\text { Leaves } \\
\text { surface }\end{array}$} & \multicolumn{2}{c|}{ Biomass, g/plant } \\
\cline { 5 - 5 } & area, $\mathrm{dm}^{2}$ & Beet tops & Leaf blade \\
\hline Control - without treatment & 17,9 & 29,86 & 161,74 & 81,71 \\
\hline Mikrometsen $-2,5 \mathrm{ml} / \mathrm{ha}$ & 20,7 & 34,72 & 188,39 & 100,05 \\
\hline Mikrometsen - 5,0 ml/ha & 26,3 & 36,76 & 220,07 & 109,34 \\
\hline Mikrometsen - 10,0 ml/ha & 28,0 & 38,59 & 248,32 & 118,30 \\
\hline $\mathrm{SSD}_{05}$ & 1,2 & 1,64 & 9,82 & 4,80 \\
\hline
\end{tabular}

From the data presented in table 1 it can be seen that twice repeated spraying of sugar beet plants with Mikrometsen promotes the preservation of leaves in viable state for longer time (number of leaves - 20.7-28.0 pcs, control - $17.9 \mathrm{pcs} / \mathrm{plant}$; leaf area - 34.72-38.59 
$\mathrm{dm}^{2}$, control - $\left.29.86 \mathrm{dm}^{2}\right)$, as well as an increase in the tops biomass (188.39-248.32, control - $161.74 \mathrm{~g}$ ) and leaf blades (100.05 -118.30, control - $81.7 \mathrm{~g})$. Moreover, the absolute values of the indicators considered in table 1 enhanced with increasing dose of the chemical. Such an excess of the above mentioned indicators values in the experimental variants is due to the mechanism of action of the test chemical.

Recently, to regulate the processes of growth of the leaf apparatus of row crops and sugar beet root crops and consequently yield management, growth regulators have been used $[12,13,14,15]$. Also, organophosphorus including phosphinic acids and their various derivatives are known to be used as plant growth regulators. The direct inclusion of growth regulators in the metabolic processes when spraying sugar beet plants twice enhances not only the growth processes (Table 1) but also the formation processes (Table 2).

Table 2. Effect of Mikrometsen on formation of root crops

\begin{tabular}{|l|c|c|c|}
\hline \multicolumn{1}{|c|}{ Option } & $\begin{array}{c}\text { Length of root crop, } \\
\mathrm{cm}\end{array}$ & $\begin{array}{c}\text { Diameter of root } \\
\text { crop, cm }\end{array}$ & $\begin{array}{c}\text { Mass of root } \\
\text { crop, } \mathrm{g}\end{array}$ \\
\hline Control - without treatment & 27,8 & 6,9 & 417,26 \\
\hline Mikrometsen $-2,5 \mathrm{ml} / \mathrm{ha}$ & 29,4 & 7,4 & 438,93 \\
\hline Mikrometsen $-5,0 \mathrm{ml} / \mathrm{ha}$ & 29,8 & 7,6 & 447,24 \\
\hline Mikrometsen $-10,0 \mathrm{ml} / \mathrm{ha}$ & 32,3 & 8,0 & 461,24 \\
\hline $\mathrm{SSD}_{05}$ & 1,4 & 0,4 & 20,64 \\
\hline
\end{tabular}

An analysis of the data in Table 2 shows that the spraying of sugar beet plants with the test chemical, enhancing assimilation processes, the accumulation of assimilates and their rational redistribution to root crops, contributed to the formation of larger root crops (length 29.4-32.3, control - $27.8 \mathrm{~cm}$; diameter - 7.4-8.0, control - $6.9 \mathrm{~cm}$ ) and mass (438.93461.24, control - 417.26 g). The largest root crops were formed in the option using the test chemical at a dose of $10.0 \mathrm{ml} / \mathrm{ha}$. Obviously, more favorable conditions were created in this option accompanied by normalization of the water balance, increased resistance to climatic stresses (high temperature, drought), accelerated growth and production processes, which resulted in an increase in yield and sugar harvesting per hectare (table 3 ).

Table 3. Effect of Mikrometsen on yield of sugar beet and sugar per hectare

\begin{tabular}{|l|c|c|c|c|c|}
\hline \multirow{2}{*}{ Option } & \multirow{2}{*}{$\begin{array}{c}\text { Yield, } \\
\text { centner/ha }\end{array}$} & \multicolumn{2}{|c|}{ Supplement to control } & $\begin{array}{c}\text { Sugar } \\
\text { content, } \\
\%\end{array}$ & $\begin{array}{c}\text { Sugar yield } \\
\text { per hectare, } \\
\text { centner }\end{array}$ \\
\hline Control - without treatment & 365,9 & - & - & 15,9 & 58,18 \\
\hline Mikrometsen - 2,5 ml/ha & 390,7 & 24,8 & 6,8 & 16,3 & 63,68 \\
\hline Mikrometsen - 5,0 ml/ha & 397,5 & 31,6 & 8,6 & 16,7 & 66,38 \\
\hline Mikrometsen - 10,0 ml/ha & 410,1 & 44,2 & 12,1 & 17,1 & 70,13 \\
\hline $\mathrm{SSD}_{05}$ & 17,9 & & & & \\
\hline
\end{tabular}

The maximum yield increase $12.1 \%$ (Table 3) with a yield of 365.9 centner/ha of root crops in control was obtained in the option with the spraying of vegetative sugar beet plants with Mikrometsen at a dose of $10.0 \mathrm{ml} /$ ha twice (in phase 4-6 leaves and again after 20 days). The sugar yield per hectare in the indicated option increased by $20.5 \%(70.13$, control -58.18 centners) due to the increase in yield and sugar content in root crops (17.1, control - $15.9 \%$ ).

Thus, the results of our studies and the ones previously conducted by other researchers $[11,12,13,14,15]$ showed that the formation of reproductive organs cannot do without applying organic acids, growth regulators, and agrochemicals. 


\section{Conclusion}

Twice repeated spraying of vegetative plants of sugar beet (1st in the phase of 4-6 leaves and again after 20 days) with Mikrometsen activates the growth of tops. A more powerful leaf rosette was formed when applying the chemical Mikrometsen in a technology of sugar beet cultivation at a dose of $10.0 \mathrm{ml} /$ ha (consumption rate of working solution $200 \mathrm{l} / \mathrm{ha}$ ), which ensured maximum yield increase of $12.1 \%$ (root crops yield -410.1 centner/ha, control - 365.9 centner/ha) and maximum content of sugar $(70.13$, control - 58.18 centner).

\section{Reference}

1. M. U. Mubarak, M. Zahir, S/ Ahmad, A.Wakeel, JIA. Vol., 15, 2620-2626 (2016) https://doi.org/10.1016/B978-0-12-814138-0.00013-7

2. K.O. Siniashin, Bis (hydroxymethyl) phosphinic acid and its salts with biogenic metals as plant growth and development regulators / K.O. Siniashin, A.Ya. Barchukova, M.M. Shulaeva // Patent for invention RUS 2624627 C1 05.07.2017. Application № 2016140004 ot 11.10.2016. Access mode: https://elibrary.ru/download/elibrary 38267111 70593392.pdf

3. H-A.A. Hussein, B.B. Mekki, M. E. Abd El-Sadek, E. Ebd El Lateef, Heliyon, 5, 8 (2019) https://doi.org/10.1016/j.heliyon.2019.e02631.

4. B. Yu, J. Li, J. Koh C. Dufresne, N. Yang, Sh. Qi, Y. Zhang, Ch. Ma, B. V. Duong, S. Chen, H. Li. J, of Proteomics, 143, 286-207 (2016) https://doi.org/10.1016/j.jprot.2016.04.011

5. A. A.Gusev, A. A.Kudrinsky, O. V. Zakharova, A. I. Klimov, P. M. Zherebin, G. V. Lisichkin, I. A. Vasyukova, A. N. Denisov, Y. A. Krutyakov, Materials Sci. and Engineering, 62, 152-159 (2016) https://doi.org/10.1016/j.msec.2016.01.040

6. R. Mandershied, A. Pacholski, H.-J. Weigel, European J. of Agronomy, 32, 228-230 (2010) https://doi.org/10.1016/j.eja.2009.12.002

7. D. Laufer, H.-J. Koch, European J. of Agronomy, 82, 182-189 (2017) https://doi.org/10.1016/j.eja.2016.10.017

8. R. Marchetti, F. Castelli, European J. of Agronomy, 35, 13-21 (2011) https://doi.org/10.1016/j.eja.2011.03.003

9. T. V. Nest, B. Vandecasteele, G. Ruysschaert, M. Cougnon, R. Merckx, D. Reheul, Agr., Ecosystems\&Envir., 197, 309-317 (2014) https://doi.org/10.1016/j.agee.2014.07.019

10. P. M. Nkebiwe, M. Weinmann, A. Bar-Tal, T. Muller, Field Crops Research, 196, 389-401 (2016) https://doi.org/10.1016/j.fcr.2016.07.018

11.S. Kiymaz, A. Ertek, Agr. Water Management, 158, 156-165 (2015) https://doi.org/10.1016/j.agwat.2015.05.004

12. S.V. Soloviev Agrotechniques, growth regulators and yield of industrial sugar beet in the conditions of North-West of Tambov region / S.V. Soloviev, A.I. Geraskin, // Herald of Michurin State Agrarian University, 2, 92-94 2010 Access mode: https://elibrary.ru/download/elibrary 1672707769398629.pdf

13. T.S. Per, N.A. Khan, P.S. Reddy, A. Masood, M. Hasanuzzaman, M. I. R.Khan, N. A. Anjum, PPB, 115, 126-140 (2017) https://doi.org/10.1016/j.plaphy.2017.03.018

14. D.N. Zapisotskiy Effect of plant growth-regulators applying on height and growth of aboveground organs mass of soya beans / D.N. Zapisotskiy, A.Ya. Barchukova // Рисоводство, 3(40), 58-61 2018 Access mode: https://elibrary.ru/download/elibrary 37036949 30187051.pdf

15. A.A. Gusev, A.A. Kudrinsky, O.V. Zakharova, A.I. Klimov, P.M. Zherebin, G.V. Lisichkin, I.A. Vasyukova, A.N. Denisov, Y.A. Krutyakov. Materials Sci. and Engineering, 62, 152-159 (2016) https://doi.org/10.1016/j.msec.2016.01.040 